\title{
Association between diabetics and intestinal cancer with the risk of mutation in CD38 gene in Iranian population
}

\author{
Mohammad SHOKRZADEH ${ }^{1}$, Pouya GOLEIJ ${ }^{2}$, Elmira BEHRAVAN ${ }^{3}$, Nasrin GHASSEMI-BARGHI ${ }^{1}$, \\ Yaser SALEHABADI ${ }^{1}$ and Abolhasan REZAE ${ }^{3}$
}

\begin{abstract}
Background - Intestinal cancer often occurs in type 2 diabetic patients. The concept of increasing insulin levels and insulin-like growth factor in the blood with type 2 diabetes are stimulated with the growth and depletion of cloned cell walls, and the continuation of this process leads to the cellular deformation. This is the evidence for intestinal cancer in type 2 diabetes in population. Objective - In this study, we aimed to find out the relationship between diabetics and intestinal cancer based on CD38 gene mutation. Methods - Samples were collected from 200 population including normal and case ones. PCR products related to rs 6449181 of CD38 gene was amplified with ARMS-PCR technique, and a 420-bp sharp banding was observed as well. According three ARMS-PCR techniques, three primers were designed by oligo 7 software. Primers include F1, F2 and R (amplifying for normal, mutant and reverse primer respectively). Results - This band was observed using a primer F1 that carries the wild type nucleotide using a primer, and when it is used with the F2 primer, it brings the mutant primer to populations of patients with diabetes and diabetes-cancer. In addition, the clinical results including body mass index, blood glucose and insulin level were analyzed. The means \pm SD and Tuckey's post hoc test were significant between the clinical characterization parameters between cases and healthy populations. The allelic gene frequencies and Hardy-Weinberg equilibrium between nucleotides were evaluated, and the significant level between the alleles and gene frequencies was observed. Conclusion-In general, the current study found that there is a relationship between diabetes and intestinal cancer among the studied populations.
\end{abstract}

HEADINGS - Type 2 diabetes mellitus. Intestinal neoplasms. Genotype. Genetic polymorphism.

\section{INTRODUCTION}

Type 2 diabetes is prevalent for all age groups throughout the world, and it was estimated to be $2.8 \%$ in 2000 , and this percentage grew significantly to $4.4 \%$ in $2030^{(1)}$. Probably, the rate of diabetes will increase to 366 million people by $2030^{(1,2)}$. Hence, identification, taking care, education about symptoms of diabetes is necessary ${ }^{(2)}$. The current study, which we focused, is the association between type 2 diabetic and intestinal cancer. Several studies showed that there is a relationship between diabetes type 2 and human cancer, especially colorectal cancer ${ }^{(3,4)}$. Moreover, the progression of the colon tumor becomes faster when the amount of insulin in the blood gets more ${ }^{(5,6)}$. The concept of increasing insulin levels and insulin-like growth factor (IGF) in the blood with type 2 diabetes are stimulated with the growth and depletion of cloned cell walls, and the continuation of this process leads to the cellular deformation $^{(7-9)}$. This is the evidence for intestinal cancer in type 2 diabetes in population ${ }^{(10)}$. At this time, we studied mutations in CD38 gene in the intestinal cancer population. CD38 is known as the cyclic ADP ribosome hydrolase. A glycoprotein that is found on the surface of many immune cells (white blood cells), including CD4+, CD8+, $\mathrm{B}$ lymphocytes, and natural killer cells. CD38 also acts in cell adhesion, signal transduction, and calcium signaling ${ }^{(11,12)}$.
In humans, the CD38 gene located in the short arm of chromosome 4. This gene has eight exons in $15 \mathrm{p} 4$, and it has a length of $70 \mathrm{kbp}^{(13,14)}$. The genetic and autoimmune characteristics of CD38 protein are associated with diabetes. A study of the potential pathological pathways of insulin secretion by CD38 was discovered in a CD38 (Arg140Trp) gene mutation among 13\% of Japanese type 2 diabetic patients with family history ${ }^{(15-17)}$. From 1990 to 2013 the rate of colorectal cancer increased by death (around 57\%). The epidemiological studies suggest that diabetic mellitus especially diabetic type 2 mellitus (T2DM), associated with increased risk of cancer at several sites, including colorectal and intestinal cancer ${ }^{(18-20)}$. Furthermore, Ma et al., 2008 proposed that prostate tumors contained multiple Gleason grades as well as multiple cancer cell types that were distinguishable by their cluster designation $(\mathrm{CD})$ phenotypes $^{(21)}$. Generally CD38 related to risk of diabetics associated with most cancers like, the breast, liver, pancreas, Colorectal, endometrium, kidney and urinary bladder ${ }^{(22)}$.

Moreover, the underlying mechanisms for a higher risk of cancer in patients with diabetes may be concerned with the insulin resistance, poor glycemic control, oxidative stress and pro-inflammatory status ${ }^{(23)}$. Studies on the intestinal cancer is very low but regarding to the same cancer, specially colorectal cancer, which was reported, the related risk factors are shared by diabetic type 
2 mellitus, and the targeted organ damage may be confounders in epidemiological studies ${ }^{(24)}$. Obesity is a major risk factor for diabetic type 2 mellitus, cancer and diabetic kidney disease (DKD) ${ }^{(10)}$. In this study, we can consider two parameters including: A) is there a relationship between diabetics and CD38 gene? B) Is there a relationship between CD38 and intestinal cancer? However, studies by researchers confirmed association between diabetics and intestinal cancers; however, we focus on both the diabetic and intestinal cancer in a case what would happen about it.

\section{METHODS}

\section{Sample preparation}

The samples were provided from 200 people including 100 control cases and 100 patients from the North of Iran. (TABLE 1).

TABLE 1. Characteristics of patients and healthy controls.

\begin{tabular}{lcccc}
\hline \multirow{2}{*}{ Sample } & Number & Age (mean) & \multicolumn{2}{c}{ Gender } \\
\cline { 4 - 5 } & & 55 & Male & Female \\
\hline Patient & 100 & 50 & 53 & 32 \\
Normal & 100 & & & 47 \\
\hline
\end{tabular}

TABLE 2. PCR program and its reaction for getting sharp band on the gel electrophoresis.

\begin{tabular}{lc}
\hline Component & Volume \\
\hline Template DNA $(100 \mathrm{ng} / \mu \mathrm{L})$ & $4.0 \mu \mathrm{L}$ \\
Forward primer $(10 \mathrm{pmol} / \mu \mathrm{L})$ & $0.5 \mu \mathrm{L}$ \\
Reverse primer $(10 \mathrm{pmol} / \mu \mathrm{L})$ & $0.5 \mu \mathrm{L}$ \\
$\mathrm{dNTP} \operatorname{mix}(2.5 \mathrm{mM} \mathrm{each})$ & $1.0 \mu \mathrm{L}$ \\
$10 \mathrm{X}$ buffer & $2.5 \mu \mathrm{L}$ \\
$\mathrm{MgCl}_{2}$ & $2.5 \mu \mathrm{L}$ \\
Taq enzyme $(3 \mathrm{U} / \mu \mathrm{L})$ & $0.5 \mu \mathrm{L}$ \\
Water & $13.5 \mu \mathrm{L}$ \\
Total reaction volume & $25.0 \mu \mathrm{L}$ \\
\hline
\end{tabular}

TABLE 3. PCR cycle condition.

\begin{tabular}{lccccc}
\hline Temperature & $94^{\circ} \mathrm{C}$ & $95^{\circ} \mathrm{C}$ & $61.5^{\circ} \mathrm{C}$ & $72^{\circ} \mathrm{C}$ & $72^{\circ} \mathrm{C}$ \\
\hline Time & $5 \mathrm{~min}$ & $30 \mathrm{sec}$ & $40 \mathrm{sec}$ & $30 \mathrm{sec}$ & $10 \mathrm{~min}$ \\
Cycles & & $40 \mathrm{cycle}$ & & & \\
\hline
\end{tabular}

The patients with at least three criteria were acquired for lab measurement including the subjects:obesity, fasting blood glucose, the level of LDL (low-density lipoprotein) and HDL (high-density lipoprotein). The thesis code is 15930503952005.

\section{Extraction of genomic DNA and doing PCR}

Genomic DNA of 200 samples above were isolated from 100 $\mathrm{CC}$ of blood with extracted ones using a standard kit GENET Bio. In order to make sure ourselves that DNA has the high quality, extracted DNA was placed on $1.5 \%$ Agarose gel. The concentration of DNA genomic was calculated, and it is ready for doing PCR ${ }^{(25)}$.

\section{Three ARMS-PCR Process}

One pair of primer forward and one primer of reverse were designed on the partial fragment of CD38 gene based on rs: 6449181;

Forward1: GGCCCATCAGTTCACACAGGTCCAGC

Forward2: GGCCCATCAGTTCACACAGGTCCAGt

Reverse: AAATGCCAGCTCCCCTTCCCC

Note: Primers after designing were alignment with NCBI Network system (BLAST) and confirmed accuracy current primers with CD38 gene based rs6449181.

According to above primers, PCR program and its reaction were applied for getting sharp band on the gel electrophoresis as TABLE 2. PCR cycle condition is summarized in TABLE 3. PCR products were running on 1.5 percent gel electrophoresis to determine the quantity and quality of PCR products.

\section{Sequencing and Sequence Analysis of Fragment of CD38 Gene}

For accuracy of amplification of CD38 gene, it was sequenced and analyzed by Bioedit software version of 5.0.

\section{Statistical analysis}

Data were analyzed by SPSS software (version 20) using oneway analysis of variance. The Tukey post hoc test was used at the significant level of $P<0.05$.

\section{RESULTS}

\section{Hormonal analysis}

TABLE 4 revealed that hormonal and biochemical analysis can be considered as the means $\pm \mathrm{SD}$, and Tuckey's post hoc test. One-way ANOVA calculated the correlation between clinical characterizations and four groups (control, diabetics, cancer and cancer\& diabetics). Due to the comparison between control,

TABLE 4. Mean value of anthropometric, metabolic program and heritability of control, diabetics, cancer-diabetic population.

\begin{tabular}{|c|c|c|c|c|c|}
\hline Source & $\begin{array}{l}\text { Normal } \\
(n=50)\end{array}$ & $\begin{array}{l}\text { Diabetic } \\
(\mathrm{n}=25)\end{array}$ & $\begin{array}{l}\text { Cancer } \\
(n=25)\end{array}$ & $\begin{array}{c}\text { Cancer-diabetic } \\
(\mathrm{n}=25)\end{array}$ & $\begin{array}{c}\text { Statistical } \\
\text { significance }\end{array}$ \\
\hline Body mass index & $26.23 \pm 3.32$ & $\begin{array}{l}31.56 \pm 2.32 \\
30.50 \pm 2.80 \\
31.50 \pm 2.82\end{array}$ & & & $P<0.05$ \\
\hline Fasting insulin $(\mu \mathrm{UI} / \mathrm{mL})$ & $10.88 \pm 2.43$ & $14.65 \pm 2.34$ & $14.61 \pm 2.20$ & $15.61 \pm 2.30$ & $P<0.001$ \\
\hline Fasting blood glucose $(\mathrm{mg} / \mathrm{dL})$ & $92.32 \pm 6.55$ & $178.32 \pm 9.80$ & $170.45 \pm 10.30$ & $171.42 \pm 10.30$ & $P<0.001$ \\
\hline HDL-C (mg/dL) & $60.65 \pm 8.1$ & $54.34 \pm 5.45$ & $52.55 \pm 4.50$ & $52.34 \pm 4.50$ & $P<0.001$ \\
\hline LDL-C (mg/dL) & $100.65 \pm 10.1$ & $165.34 \pm 10.45$ & $166.50 \pm 1.06$ & $166.30 \pm 1.06$ & NS \\
\hline
\end{tabular}

HDL-C: high-density lipoprotein cholesterol; LDL-C: low-density lipoprotein cholesterol; NS: not significant. 
diabetics, cancer and the cancer with diabetes, it shows the high BMI, HDL cholesterol, fasting insulin and fasting blood glucose with significant index, along with the lower LDL cholesterol with insignificant index.

Clinical records of the control and patient groups including gender, heritability and history hyperglycaemia is shown in TABLE 5. By right of, nine samples were randomly selected to study the clinical records. The results show that the most cases have had the history of the inheritance diseases in family along with the history of diabetics and intestinal cancer diseases in family. FIGURE 1 shows that the status of distribution of the intestinal cancer in cases. Because of it, the range of incidence was 40 to 80 years old, and threshold of incidence was 70-80 years old.

TABLE 5. Clinical records of the control and patient groups including gender, heritability and history hyperglycaemia in patients is shown.

\begin{tabular}{lccc}
\hline Sex & $\begin{array}{c}\text { The history } \\
\text { of inheritance } \\
\text { diseases in } \\
\text { family }\end{array}$ & $\begin{array}{c}\text { The history of } \\
\text { diabetics and } \\
\text { intestinal cancer } \\
\text { diseases in family }\end{array}$ & $\begin{array}{c}\text { Hyper } \\
\text { glycemic }\end{array}$ \\
\hline Male & No & Yes & Yes \\
Male & Heart diseases & No & No \\
Male & No & $\begin{array}{c}\text { Diabetics-cancer } \\
\text { (his sister) }\end{array}$ & Yes \\
Female & Diabetic-Hepatic & $\begin{array}{c}\text { Diabetics } \\
\text { (her brother) }\end{array}$ & Yes \\
Female & No & No & Yes \\
Male & No & No & No \\
Female & No & No & Yes \\
Female & No & Diabetics-cancer \\
(her brother) & No \\
Female & No & Cancer only & Yes \\
\hline & & (her brother and sister) & \\
\hline
\end{tabular}

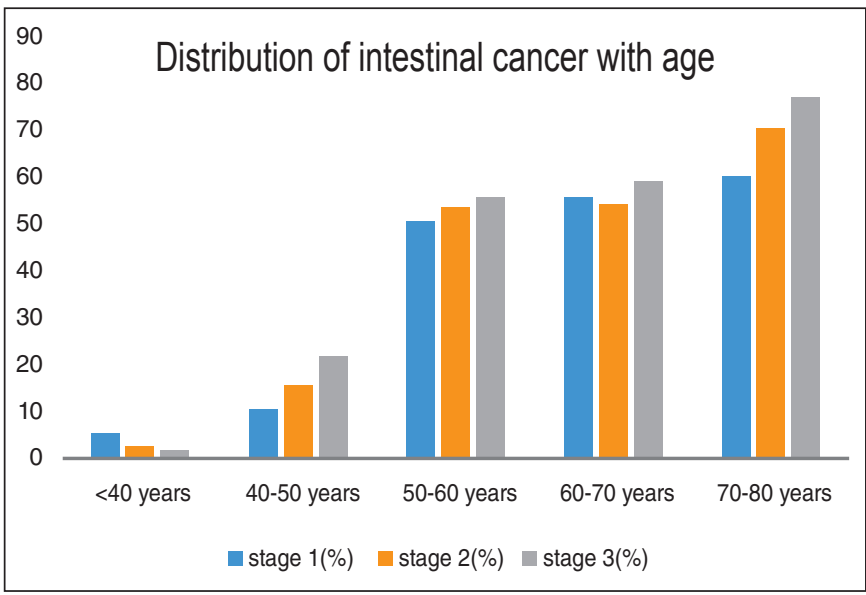

FIGURE 1. The distribution of the intestinal cancer related to the age showed that the most of cases belong to the range of $70-80$ year old people.
FIGURE 2 shows that PCR product of CD38 gene is amplified by normal primer. The results show a $420 \mathrm{bp}$ fragment is related with the amplified rs6449181 of CD38 gene.

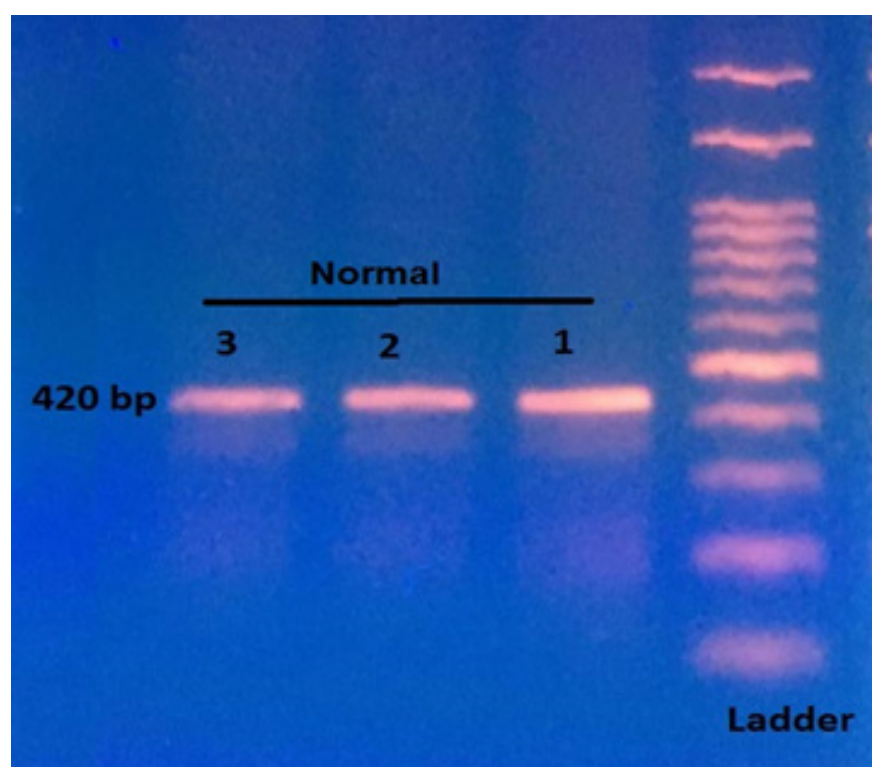

FIGURE 2. PCR product of rs6449181 of CD38 gene in normal group when used normal primer (F1) (lane 1, 2 and 3 and Ladder). The size of PCR product is sharp showing $420 \mathrm{bp}$.

FIGURE 3 shows that PCR product of CD38 gene is amplified by mutant primer (lane 1, 3 and 4). Lane 2 is the control group, that is, the group without using primers of CD38 gene. The results show a sharp band in $420 \mathrm{bp}$ length is related with rs6449181. The results show a $420 \mathrm{bp}$ fragment related to rs6449181 of the amplified CD38 gene.

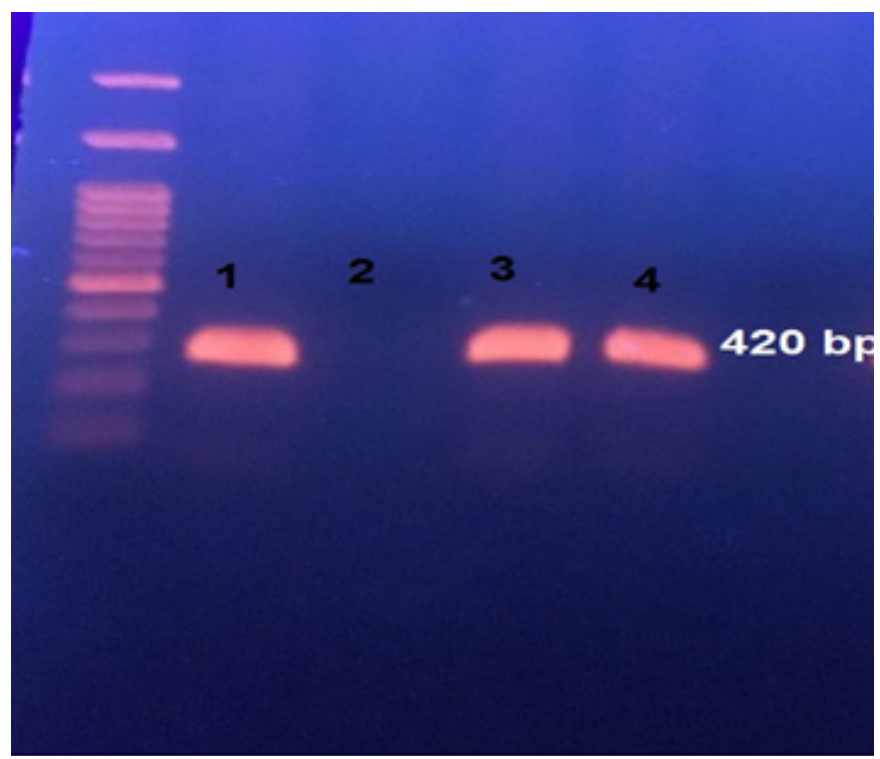

FIGURE 3. PCR product of rs6449181 of CD38 gene in cases group when used normal primer (F2) (lane 1, 3 and 4 is mutant and line of 2 is control group). The size of PCR product is sharp that was $420 \mathrm{bp}$. 
FIGURE 4 shows the alignment of the partial CD38 gene and CD38 gene in GenBank for verifying the results of three, amplification. The results show that both sequences have high homology, and they verified our PCR amplification. TABLE 6 shows the allelic and genotypic frequencies of CC, CT, and TT nucleotides of rs6449181: in CD38 gene in normal and cases group respectively. The frequencies of allelic and genotypic by Hardy-Weinberg equilibrium is insignificant between them $(P$ value $>0.05)$.

\section{DISCUSSION}

Today, various studies have shown that there is a link between diabetes and cancers in the gastrointestinal tract. Mellitus diabetes may increase the risk of many cancers, including breast, liver, pancreatic, colon, endometrium, kidney, and lymph and bladder cancer ${ }^{(26,27)}$.

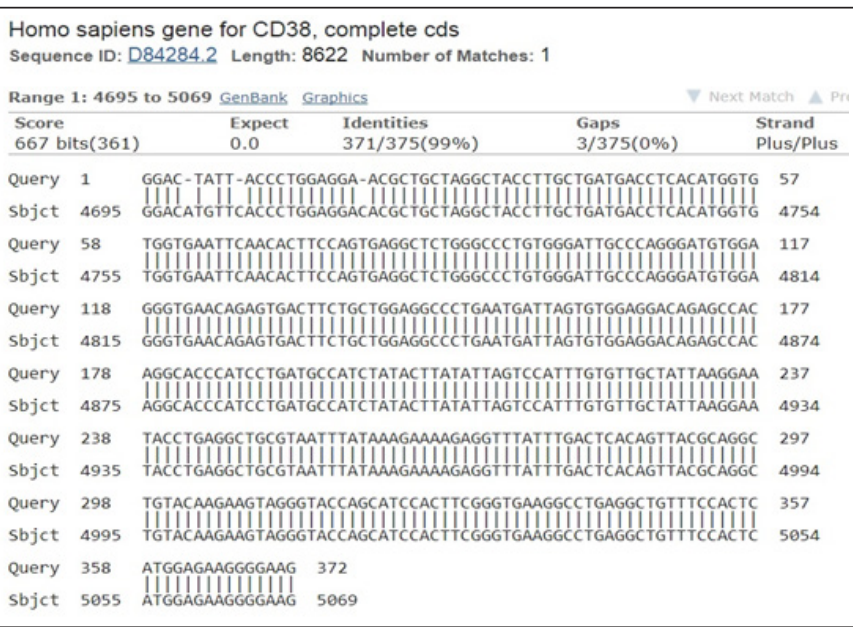

FIGURE 4. Results of BLAST analysis shows the relationship between partial CD 38 gene (query) and CD 38 gene in GenBank(Sbjct). According to our result between both sequences, the high homology is shown in the table, and it confirmed PCR product. TABLE 6. The allelic and genotypic frequencies of CC, CT, and TT nucleotides of rs:6449181 of CD38 gene in normal and patient samples, respectively.
In addition, most cancers are often related to diabetes and cancers. Insulin resistance reduced fat control, oxidative stress, and changes in the immune system. One of the most important gastrointestinal cancers is the gastric cancer, which is associated with age in men and most people ${ }^{(28,29)}$.

Obesity, smoking, salt intake, and infection with helicobacter pylori and risk factors associated with gastrointestinal cancers. In addition, gastrointestinal cancers, especially gastric cancer, are abundant in developing countries such as the Middle East, South America. While it is low in North America and some parts of Africa ${ }^{(30,31)}$.

The aim of this study is to evaluate the relationship between diabetes and one of the digestive cancers, such as intestinal cancer, based on the part of the CD38 gene in Iran.

The results of FIGURES 2, 3 and 4 shows that there is a relationship between mutations in rs: 6449181 of the CD38 gene with intestinal cancer by help of the ARMS-PCR technique.

In this study, 100 controls and 100 patients were used. The patient group was divided into three groups: first, diabetes, second, cancer and third, diabetic intestinal cancer.

Our results in both groups showed that mutation is in position rs: 6449181 of CD38 gene. Moreover, our results were evaluated with the results of Chin and Farn, 2014 between the diabetic and gastric cancer population. The population related to the age increasing with gastric cancer, most of the ones who were over the age of 30 and suffering from type 1 diabetes $^{(32)}$.

In addition, in Asian countries with type 2 diabetes, gastrointestinal cancers were examined, and then significant relationships were observed. Furthermore, Chin and Farn, 2014 were compared with control group from 17 cases including 6 patients and 11 healthy people with gastric cancer disease and diabetes. In this study, only the number of people who died has been investigated and there is a significant relationship. There was also a significant relationship between the prevalence of diabetes and gastrointestinal cancers with sex, age, obesity, smoking, salt intake, and infection with H.pylori ${ }^{(32)}$. These factors vary among different populations. In generally CD38 is a multi-functional transmembrane protein that was originally identified as a cell surface receptor and marker of lymphocyte differentiation and maturity. CD38 is also a major cellular NADase that can catalyze the synthesis of a series

TABLE 6. The allelic and genotypic frequencies of CC, CT, and TT nucleotides of rs:6449181 of CD38 gene in normal and patient samples, respectively. The results showed hardy Weinberg equilibrium that insignificantly between genotypic and allelic of rs:6449181.

\begin{tabular}{|c|c|c|c|c|c|c|c|}
\hline rs:6449181 & Genotype & $\begin{array}{c}\mathbf{N} \\
(\mathrm{n}=200)\end{array}$ & $\begin{array}{l}\text { Frequency } \\
(\%)\end{array}$ & $\begin{array}{c}\text { Expected genotype } \\
\text { frequency under } \\
\text { HWE }\end{array}$ & Allele & $\begin{array}{l}\text { Allele frequency } \\
(\%)\end{array}$ & $\begin{array}{c}\text { HWE } \\
(P \text {-value })\end{array}$ \\
\hline Normal & $\mathrm{CT}$ & 48 & 50 & 50.00 & $\mathrm{~T}$ & 33.9 & \\
\hline \multirow{3}{*}{ Cases } & $\mathrm{CC}$ & 44 & 17 & 16.21 & $\mathrm{C}$ & 31.67 & $0.21 *$ \\
\hline & $\mathrm{CT}$ & 28 & 30 & 27.23 & $\mathrm{~T}$ & 68.23 & \\
\hline & TT & 8 & 53 & 54.23 & & & \\
\hline
\end{tabular}

HWE: Halfway wicket value. *Non-significant variation. 
of second messengers, including cyclic ADPribose (cADPR) and nicotinic acid adenine dinucleotide phosphate (NAADP) ${ }^{(33)}$. At least three CD38 SNPs have been reported previously, and they were used to perform genotype-phenotype correlation studies. Abramenko et al., 2012 reported that rs6449182, a common SNP in intron 1 which was not included in their amplicons for that intron; a relatively uncommon nonsynonymous SNP, rs1800561, in exon 3 that results in an Arg140Trp change in encoded amino acid that they did not observe in their samples. rs1130169 of CD38 gene revealed that significantly associated with basal mRNA expression $^{(34)}$. Although our studies are not similar, rs6449181 used here for the association between diabetic and intestinal cancer. However, we could find a relationship between them. In fact, there is a significant level of relationship between diabetic and intestinal cancer. TABLE 4 shows the regarding family inheritance. Most of the patients, who were studied, had a history of diabetes or heart disease. That is, there is a relationship between heart disease and diabetes in the present study. In addition, Scirica et al. 2013 reported that there is a relationship between a diabetes risk and the cardiovascular diseases. In fact, they suggested that there is a relationship between type 2 diabetes with the reduced incidence of two major aneurismal diseases, abdominal aortic aneurysm and subarachnoid hemorrhage ${ }^{(35)}$. Moreover, there are some relationships between increasing of blood glucose levels and heart disease. In addition, high blood glucose and high cholesterol have been observed in $90 \%$ of the heart patients. TABLE 5 shows patients' clinical parameters such as weight, fasting insulin, HDL and LDL cholesterol in normal and cases group. As we follow the diabetes and diabetic cancer, the level of blood glucoses, fasting insulin and LDL was higher than normal group. That is, the meta genomic can be cause of diseases. Moreover, sexicity is important for studies in current research. Most of population was women that apparently sexicity is engaged to relation between diabetics and cardiovascular diseases. However, aging is important for incidence of both diabetes and cancer. Beside there are some relationships between high Body mass index and risk of CRC. The prior report suggests that becoming overweight/ obese in early adulthood might affect the incidence of CRC and that body weight gain over the adult lifespan is associated with a slightly elevated CRC risk. These findings offer a significant strategy to aid the primary prevention of CRC in subjects with a high BMI starting at early adulthood ${ }^{(36)}$.

The current research shows that most of them are about 40 , and the threshold of the incidence belong to the patients who are $70-80$ years. Meta-analysis also shows the relative risks for patients with the coronary heart disease is 2.63 for women and 1.85 for men who have diabetes. Sex difference in relation with type 2 diabetes, with outcomes other than coronary heart disease, has less been reported with conflicting results for stroke. The participants who are younger than 60-year-old people are, we noted the weak evidence of a slightly stronger association of type 2 diabetes with myocardial infarction. The women, in comparison with men, are more consistent with previous reports. However, we saw no other sex differences in associations between type 2 diabetes and cardiovascular outcomes.

TABLE 6 shows the frequency of allele and genotype and the frequency of heterozygosity in normal and case group, it is higher than homozygosity alleles, which increased the risk of incidence in healthy populations. Hardy Weinberg equilibrium was also investigated, and he could be no significant effect between the frequency of the allele and the number of subjects studied. Apparently, the use of larger populations could cause a change in this situation, since most researchers from large populations have more than 200 samples and have a meaningful effect; however, this parameter cannot be $100 \%$ verified. Larsson found that there was an increased risk of small intestine cancers (2.1 to 3.1 times) among diabetic patients who suffered from obesity for 4 years or more. The relationship between the incidence of obesity and the increased risk of cancer indicated the long-term effect of insulin on the risk of developing cancer ${ }^{(37)}$.

The risk of developing intestine cancers increased with the duration of obesity and type 2 diabetes. Stattin et al., 2004, also found that the age will could have a significant role in the development of cancer and its relation with diabetes. In this regard, people aged 50 to 60 years were about $21.8 \%$ more likely than others to have cancer and diabetes were ${ }^{(38)}$. The impact of sex is also important in the development of cancer and diabetes, some cancers are more common in women, such as breast, uterine, and in men, prostate cancer, while men are more susceptible to diabetes than women ${ }^{(39)}$. Finally, we can conclude that CD38 gene has a relationship with type 2 diabetics that associated with intestinal cancer. Our aim in this sturvey is to study the situation of association between diabetic and cancer based CD38 gene. The functional this gene is autoimmune which is related with several human cancers. In the present study, we analyze and observe the significant effect of mutation on the part of the CD38 gene, which is rs:6449181, and besides it's associated with cancer and diabetes.

The subjects were often over 40 years old and were collected from the Mazandaran Province. ARMS-PCR results indicate the evaluated mutation for both patients and healthy subjects. FIGURE 4 shows that sequences of partial fragment of CD38 gene while alignment is with BLAST program. However, that is not position of rs: 6449181, it is confirmed both the partial CD38 gene and PCR amplification. Finally, we concluded that there is a relationship between intestinal cancer and diabetic syndrome based on rs: 6449181 of CD38 gene. Moreover, our result showed that the rate of incidence in heterozygote allelic is more than homozygote population. Hence, we should study more population in Iran.

\section{Authors' contribution}

Shokrzadeh M: study design and management.Rezaei A: study design and management. Goleij P and Salehabadi Y: perform tests. Ghassemi-Barghi N: statistical analyses. Behravan E: writing article, all authors read and approve final manuscript.

\section{Orcid}

Mohammad Shokrzadeh: 0000-0002-0071-6530.

Nasrin Ghassemi-Barghi: 0000-0002-0673-4262.

Abdolhasan Rezaei: 0000-0001-5062-5832.

Pouya Goleij: 0000-0002-2213-497X.

Elmira Behravan: 0000-0001-5532-6399.

Yaser Salehabadi: 0000-0002-9894-2076. 
Shokrzadeh M, Goleij P, Behravan E, Ghassemi-Barghi N, Salehabadi Y, Rezaei A. Associação entre diabéticos e câncer intestinal com o risco de mutação no gene CD38 na população iraniana. Arq Gastroenterol. 2020;57(2):144-9.

RESUMO - Contexto - $O$ câncer intestinal ocorre frequentemente em pacientes diabéticos tipo 2 . O conceito que aumento dos níveis de insulina e fator de crescimento semelhante à insulina no sangue com diabetes tipo 2 sejam estimulados com o crescimento e esgotamento das paredes celulares clonadas, e a continuação desse processo levaria à deformação celular. Esta é a evidência para câncer intestinal em diabetes tipo 2 na população. Objetivo Neste estudo, buscou-se descobrir a relação entre diabéticos e câncer intestinal com base na mutação genética CD38. Métodos - Foram coletadas amostras de duzentos habitantes, incluindo os normais e os casos. Produtos PCR relacionados ao rs 6449181 do gene CD38 foi amplificado com a técnica ARMS-PCR, e uma banda afiada de 420 bp também foi observada. De acordo com três técnicas ARMS-PCR, três primers foram projetados pelo software Oligo 7. Os primers incluem F1, F2 e R (amplificando para primer normal, mutante e reverso, respectivamente). Resultados - Esta banda foi observada usando um primer F1 que carrega o nucleotídeo do tipo selvagem usando um primer e quando é usado com o primer F2, ele traz o primer mutante para populações de pacientes com diabetes e diabetes-câncer. Além disso, foram analisados os resultados clínicos, incluindo índice de massa corporal, glicemia e nível de insulina. As médias \pm SD e Tuckey's post hoc test foram significativas entre os parâmetros de caracterização clínica entre os casos e populações saudáveis. Foram avaliadas as frequências genéticas alélicas e o equilíbrio de Hardy-Weinberg entre nucleotídeos e observou-se o nível significativo entre os alelos e as frequências genéticas. Conclusão - Em geral, o presente estudo constatou que há relação entre diabetes e câncer intestinal entre as populações estudadas.

DESCRITORES - Diabetes mellitus tipo 2. Neoplasias intestinais. Genótipo. Polimorfismo genético.

\section{REFERENCES}

1. Zhang P-H, Chen Z-W, Lv D, Xu Y-Y, Gu W-L, Zhang X-H, et al. Increased risk of cancer in patients with type 2 diabetes mellitus: a retrospective cohort study in China. BMC Public Health. 2012;12:567.

2. Ren X, Zhang X, Gu W, Chen K, Le Y, Lai M, et al. Type 2 diabetes mellitus associated with increased risk for colorectal cancer: evidence from an international ecological study and population-based risk analysis in China. Public Health. 2009; 123:540-4

3. Szablewski L. Diabetes mellitus: influences on cancer risk.Diabetes Metab Res Rev. 2014;30:543-53.

4. Hassani M, Ghassemi-Barghi N, Modanloo M, Mohammadpour A, Shokrzadeh M. Cytotoxic effects of duloxetine on MKN45 and NIH3T3 cell lines and genotoxic effects on human peripheral blood lymphocytes. Arq Gastroenterol. 2019;56:372-6.

5. Braun S, Bitton-Worms K, LeRoith D. The link between the metabolic syndrome and cancer.Int J Biol Sci. 2011;7:1003.

6. Ansari M, Shokrzadeh M, Karima S, Rajaei S, Fallah M, Ghassemi-Barghi N, et al. New thiazole-2 (3H)-thiones containing 4-(3, 4, 5-trimethoxyphenyl) moiety as anticancer agents. Eur J Med Chem. 2020;185:111784.

7. Beam HA, Russell Parsons J, Lin SS. The effects of blood glucose control upon fracture healing in the BB Wistar rat with diabetes mellitus. J Orthop Res. 2002;20:1210-6

8. Clemmons DR, Busby Jr WH, Brewer MT, Eisenberg SP, Thompson RC. Method for potentiating and inhibiting insulin-like growth factor activity. Google Patents; 1999.

9. Mohammadi H, Ghassemi-Barghi N, Malakshah O, Ashari S. Pyrethroid exposure and neurotoxicity: a mechanistic approach. Arh Hig Rada Toksikol. 2019; 70:74-89.

10. Giovannucci E, Harlan DM, Archer MC, Bergenstal RM, Gapstur SM, Habel LA, et al. Diabetes and cancer: a consensus report. CA Cancer J Clin. 2010;60:207-21.

11. Wang L-F, Huang C-C, Xiao Y-F, Guan X-H, Wang X-N, Cao Q, et al. CD38 deficiency protects heart from high fat diet-induced oxidative stress via activating Sirt3/FOXO3 pathway. Cell Physiol Biochem. 2018;48:2350-63.

12. Ghassemi-Barghi N, Varshosaz J, Etebari M, Dehkordi AJ. Role of recombinant human erythropoietin loading chitosan-tripolyphosphate nanoparticles in busulfan-induced genotoxicity: Analysis of DNA fragmentation via comet assay in cultured HepG2 cells. Toxicol in Vitro. 2016;36:46-52.

13. Ghassemi-Barghi N, Etebari M, Jafarian-Dehkordi A. Protective effect of amifostine on busulfan induced DNA damage in human hepatoma cells. Toxicol Mech Methods. 2017;27:52-7.

14. Kröber A, Seiler T, Benner A, Bullinger L, Brückle E, Lichter P, et al. VH mutation status, CD38 expression level, genomic aberrations, and survival in chronic lymphocytic leukemia. Blood. 2002;100:1410-6.

15. Antonelli A, Tuomi T, Nannipieri M, Fallahi P, Nesti C, Okamoto H, et al. Autoimmunity to CD38 and GAD in type I and type II diabetes: CD38 and HLA genotypes and clinical phenotypes. Diabetologia. 2002;45:1298-306.
16. Lian-xiang C, Ben-sui N, Xiang-ping L. (Department of Endocrine of Baoan District Hospital, Shenzhen 518101, Guangdong, P. R. China). Study on the clinical diagnostic criteria of latent autoimmune diabetes in adults. China Tropical Medicine. 2005;3. Available from: http://en.cnki.com.cn/Article_en/ CJFDTotal-RDYX200503014.htm

17. Shokrzadeh M, Ghassemi-Barghi N. Melatonin loading chitosan-tripolyphosphate nanoparticles: Application in attenuating etoposide-induced genotoxicity in HepG2 cells. Pharmacology. 2018;102:74-80.

18. Shokrzadeh M, Mohammadpour A, Modanloo M, Hassani M, Barghi NG, Niroomand P. Cytotoxic effects of aripiprazole on MKN45 and NIH3T3 cell lines and genotoxic effects on human peripheral blood lymphocytes. Arq Gastroenterol. 2019;56:155-9.

19. Shokrzadeh M, Mohammadpour A, Hoseini V, Abediankenari S, Ghassemi-Barghi N, Tabari YS. Serum cytokine of IL-2, IL-10 and IL-12 levels in patients with stomach adenocarcinoma. Arq Gastroenterol. 2018;55:385-9.

20. Meyerhardt JA, Catalano PJ, Haller DG, Mayer RJ, Macdonald JS, Benson III $\mathrm{AB}$, et al. Impact of diabetes mellitus on outcomes in patients with colon cancer. J Clin Oncol. 2003;21:433-40.

21. Pascal LE, Vêncio RZ, Page LS, Liebeskind ES, Shadle CP, Troisch P, et al. Gene expression relationship between prostate cancer cells of Gleason 3, 4 and normal epithelial cells as revealed by cell type-specific transcriptomes. BMC cancer. 2009;9:452.

22. Govindarajan R, Ratnasinghe L, Simmons DL, Siegel ER, Midathada MV, Kim $\mathrm{L}$, et al. Thiazolidinediones and the risk of lung, prostate, and colon cancer in patients with diabetes. J Clin Oncol. 2007;25:1476.

23. La Vecchia C, Negri E, Decarli A, Franceschi S. Diabetes mellitus and colorectal cancer risk. Biomarkers. 1997;6:1007-10.

24. Larsson SC, Orsini N, Wolk A. Diabetes mellitus and risk of colorectal cancer: a meta-analysis. J Natl Cancer Inst. 2005;97:1679-87.

25. Albertsen M, Karst SM, Ziegler AS, Kirkegaard RH, Nielsen PH. Back to basics-the influence of DNA extraction and primer choice on phylogenetic analysis of activated sludge communities. PloS one. 2015;10:e0132783.

26. Khaw K-T, Wareham N, Luben R, Bingham S, Oakes S, Welch A, et al. Glycated haemoglobin, diabetes, and mortality in men in Norfolk cohort of European Prospective Investigation of Cancer and Nutrition (EPIC-Norfolk). BMJ. 2001;322:15.

27. Miłek T, Forysiński K, Myrcha P, Ciostek P. Diabetes association of polyps and colon cancer. Pol Przegl Chir. 2019;91:9-12.

28. Khaw K-T, Wareham N, Bingham S, Luben R, Welch A, Day N. Association of hemoglobin Alc with cardiovascular disease and mortality in adults: the European prospective investigation into cancer in Norfolk. Ann Intern Med. 2004;141:413-20.

29. Dashti SG, Li WY, Buchanan DD, Clendenning M, Rosty C, Winship IM, et al. Type 2 diabetes mellitus, blood cholesterol, triglyceride and colorectal cancer risk in Lynch syndrome. Br J Cancer. 2019:1-8. 
30. Ryder R. The potential risks of pancreatitis and pancreatic cancer with GLP-1based therapies are far outweighed by the proven and potential (cardiovascular) benefits.Diabet Med. 2013;30:1148-55.

31. Shokrzadeh M, Mohammadpour A, Ghassemi-Barghi N, Hoseini V, Abediankenari S, Tabari YS. Metallothionein-2A (rs1610216\&rs28366003) gene polymorphisms and the risk of stomach adenocarcinoma. Arq Gastroenterol. 2019;56:367-71.

32. Tseng $\mathrm{CH}$, Tseng FH. Diabetes and gastric cancer: the potential links. World journal of gastroenterology: World J Gastroenterol. 2014;20:1701.

33. Camacho-Pereira J, Tarragó MG, Chini CC, Nin V, Escande C, Warner GM, et al. CD38 dictates age-related NAD decline and mitochondrial dysfunction through an SIRT3-dependent mechanism. Cell Metab. 2016;23:1127-39.
34. Abramenko V, Yurchyshyn V, Goode P, Kitiashvili I, Kosovichev A. Detection of small-scale granular structures in the quiet sun with the new solar telescope. The Astrophysical Journal Letters. 2012;756:L27. doi 10.1088/2041-8205/756/2/L27.

35. Scirica BM, Bhatt DL, Braunwald E, Steg PG, Davidson J, Hirshberg B, et al. Saxagliptin and cardiovascular outcomes in patients with type 2 diabetes mellitus. N Engl J Med. 2013;369(14):1317-26.

36. Zheng R, Du M, Zhang B, Xin J, Chu H, Ni M, et al. Body mass index (BMI) trajectories and risk of colorectal cancer in the PLCO cohort. Br J Cancer. 2018;119:130.

37. Organization WH. Obesity: preventing and managing the global epidemic: World Health Organization; 2000

38. Stattin P, Lukanova A, Biessy C, Söderberg S, Palmqvist R, Kaaks R, et al. Obesity and colon cancer: does leptin provide a link? Int J Cancer. 2004;109:149-52.

39. Murthy VH, Krumholz HM, Gross CP. Participation in cancer clinical trials: race-, sex-, and age-based disparities. Jama. 2004;291:2720-6. 